\title{
Kenyan coral reef-associated gastropod fauna: a comparison between protected and unprotected reefs
}

\author{
T. R. McClanahan* \\ Coral Reef Conservation Project, PO Box 99470, Mombasa, Kenya and Friends World College, East African Centre, PO Box 526 , \\ Machakos, Kenya
}

\begin{abstract}
A comparative survey of prosobranch gastropods was undertaken within 3 marine parks and 3 unprotected reefs to compare faunal differences attributable to management and nonmanagement policies. The total gastropod fauna was typified by low densities and high diversity and variability in species composition. Protected reefs had a higher diversity for combined reef locations and higher species richness on reef edges and lagoons but not reef flats. Differences in reef edges are attributable to physical differences in reef aspect and wave energy but lagoon differences are attributable to human influences. Total gastropod densities were similar for comparisons between reef flat and edges but unprotected reef lagoons had higher $(p<0.001)$ densities than protected lagoons. Overall, most commercially collected species were not significantly denser in protected sites than unprotected sites. Some species such as Lambis truncata and L. chiragra were clearly more dense within protected sites, which may be attributable to shell collection in unprotected reefs. Many important commercial species including Charonia tritonis, Cassis cornuta, Turbo marmarotus, Chicoreus ramosus and Cypraecassis rufa were found at very low densities regardless of location and may naturally occur at such low densities. An experimental study of predation on the gastropod Morula granulata suggested that predation is low but may affect gastropod distribution patterns as the total gastropod density was well predicted $(r=-0.96, p<0.01)$ by predation rates on $M$. granulata. Unprotected reef lagoons had lower predation rates $(p<0.06)$ than protected lagoons. Reduced predation rates and increased densities may be caused by finfish reductions due to human fishing activities. Shell collecting appears to be affecting a few but not most populations. Less direct changes in the gastropod fauna appear to be caused by overfishing of finfish and a reduction in their predators.
\end{abstract}

\section{INTRODUCTION}

Ecological research suggests that human utilization of coral reefs not only affects exploited species populations but may indirectly affect unexploited species, community structure and ecological processes, such as productivity and the calcium carbonate balance (Sammarco 1980, 1982, Hay 1984, Hay \& Taylor 1985, Lewis 1986, Hughes et al. 1987, McClanahan \& Muthiga $1988,1989)$. Most work has focused on algae-coral-sea urchin-fish interactions and less work has been undertaken on other taxonomic groups. This study presents findings from a comparative survey of protected and unprotected reefs to determine possible effects of shell

\footnotetext{
- Present address: Center for Wetlands, University of Florida,
} Gainesville, Florida 32611, USA collecting and fishing on prosobranch gastropod populations and their community structure.

Kenyan reefs offer a unique opportunity to study differences between exploited and unexploited reefs because of the close proximity of 3 marine parks and reefs that experience various levels of fishing and shell collecting. Shell collection has recently been an environmental concern (Knowles 1970, Yaninek 1976. Evans et al. 1977, Wells 1981, Wells et al. 1983). Scientific research on population changes due to shell collection has received some preliminary attention (Brownell \& Stevely 1981, Catterall \& Poiner 1987, Poiner \& Catterall 1988) but the effects that removal may have on multiple species and community structure remain poorly studied. Recently, McClanahan \& Muthiga (1988) suggested that the removal of finfish within unprotected Kenyan reefs has caused sea urchin popu- 
lation increases and particularly increases in the rockboring sea urchin Echinometra mathaei. The removal of finfish and sea urchin population increases may also have other indirect effects on gastropod populations (Ayling 1981, Hay \& Taylor 1985). This survey was intended, not to definitively determine the effect that these factors have on their populations, distribution and diversity, but rather, as a preliminary survey to suggest possible relationships resulting from human utilization and other biological and environmental factors.

\section{STUDY SITES}

Kenya's coast south of Malindi is bordered by a nearly continuous fringing reef which lies between $100 \mathrm{~m}$ and $3 \mathrm{~km}$ from shore (Fig. 1). The 3 unprotected sites chosen within this study, Diani, Bamburi and Kanamai, lie along this fringing reef and have a ESE aspect. The 3

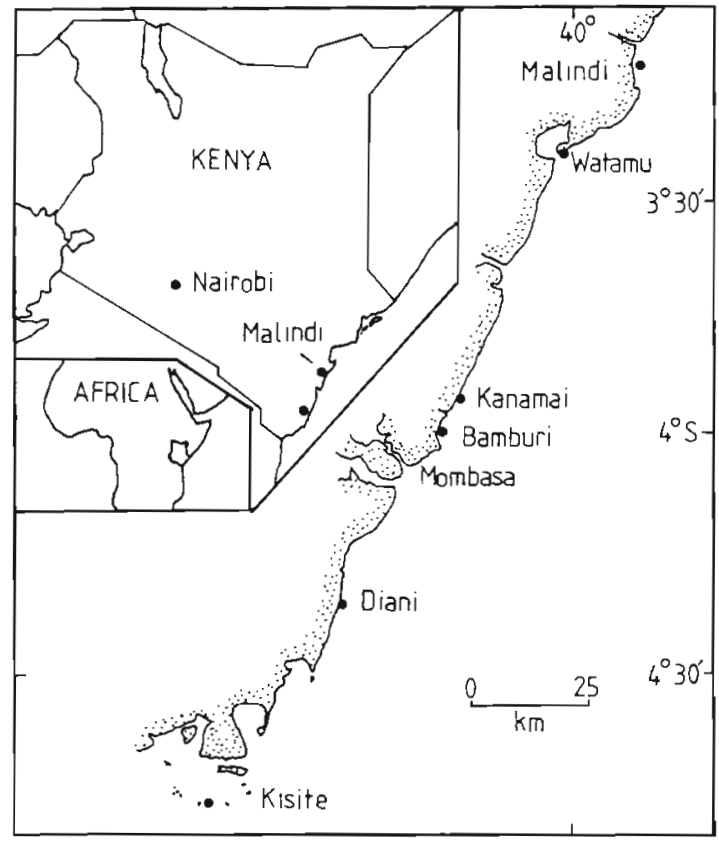

Fig. 1. Kenya's southern coastline and site locations

Marime Parks, Kisite, Watamu and Malindi, also lie along this reef but Kisite and Malindi's North Reef are separated and isolated from the major fringing reef. Kisite has a SE aspect and Malindi's North Reef and fringing reef have NE aspects. Watamu is part of the major fringing reef but the reef flat is low $10.3 \mathrm{~m}$ above datum) and rarely exposed. Nevertheless, most reefs have a reef edge, reef flat and reef lagoon. Exceptions are Malindi's fringing reef which lacks a welldeveloped reef lagoon and Watamu which has a shallow and rough reef flat and edge, not conducive to survey- ing. Therefore, sampling was only undertaken in Watamu's reef lagoon and Malindi's fringing reef flat and edge. Malindi's Small Reef and Tewa Reef were also sampled and included in the North Reef lagoon data due to their similarity in reef structure. This resulted in 3 replicate sites for each reef location and management type (protected vs unprotected). The only consistent physical differences between protected and unprotected sites is that unprotected sites may receive greater wave energy on reef edges. Their aspect faces almost directly into the prevailing swells during the southeast monsoons when wave energy is greatest (McClanahan 1988). A priori, site differences would be suspected between protected and unprotected reef edges, less for reef flats and none for reef lagoons. Strict controls for unprotected sites were not available since Park selection was independent of scientific considerations.

\section{METHODS}

Sampling was undertaken during daylight low tides: walking on reef flat and edges and snorkeling within lagoons. Reef edge sites consisted of the seaward edge of the flat between MLWN and MLWS. Reef edges were sampled exclusively during spring low tides. Only shallow $(<2.5 \mathrm{~m})$ reef lagoons were sampled. Sampling was undertaken by a $1 \mathrm{~h}$ random walk or swim within each site (Kohn 1968). During this sampling time prosobranch gastropods were identified, the time that the first individual of a species was encountered was recorded and subsequent individuals of the given species tallied. Spry (1968) is the single most useful reference for identifying East African gastropods and therefore his nomenclature is used, although it differs somewhat from more standard references (Abbott \& Dance 1986). Initial attempts to use spatial transects indicated a low density and an inefficient use of time within the intertidal zone and therefore time sampling was used. Initial studies were taken at 3 different sites to determine the optimal sample time and to determine if species richness leveled beyond a given time. Species richness did not level; therefore, a $1 \mathrm{~h}$ sample was chosen as tidal patterns allowed ca $3 \mathrm{~h}$ of reef emersion per day, which allowed each reef location to be sampled per day. Sampling was undertaken at different times for each reef between November 1986 and March 1988. Within sampling times movements were slow but continuous in order to avoid sampling restricted areas. Between sampling times different sections of the reef were sampled in order to obtain the broadest representative samples. During sampling times loose boulders were overturned and examined but only as they were encountered during the walk. Each individual site was sampled a minimum of 3 
times. A total of $82 \mathrm{~h}$ sampling, $41 \mathrm{~h}$ in each of the protected and unprotected reefs, were undertaken. Sample times are given in Table 2 .

Density (no. $\mathrm{h}^{-1}$ ) and diversity (Simpson's Index, $D=$ $\left.1-\left(n_{j} / N_{t}\right)^{2}\right)$ were calculated for each site. Simpson's Index was used instead of the Shannon Weaver Index because it is less sensitive to sample size (Kohn \& Nybakken 1975, Routledge 1979) and therefore more representative of diversity when densities are low. Species richness was determined by species-time and species-individual curves. Randomly selected $1 \mathrm{~h}$ samples were used and in the case of species-time curves average number of species found per time interval were calculated. Data were regressed to fit the equation $S=C x^{z}$ to obtain the $C$ and $z$ constants where $x$ is time in $h(t)$ or individuals $(I)$, and $S$ is the number of species.

Data from protected and unprotected reef sites were pooled for comparisons of species richness, family composition and population densities of commercial and noncommercial species. Comparisons (Mann Whitney $U$-test) of commercial and noncommercial species included 41 species of gastropods seen in shell stalls and this survey. Only 15 of the 41 species were sufficiently dense to warrant comparison and the remaining 26 species were pooled into one sample. Fifteen common noncommercial species were randomly selected to act as controls to determine if differences were attributable to collection rather than intrinsic site differences.

To determine the effect that observer bias might play in the data collection, 2 observers worked independently for $17 \mathrm{~h}$ within the same locations. During random intervals, the observer's paces per $30 \mathrm{~s}$ were recorded. The length of the observer's step was measured and field of vision estimated. The number of individuals and species encountered and the observer's rates of movement were compared.

To determine the role of predation on gastropod distribution and density, a predation experiment was undertaken. Morula granulata were attached to monofilament line $(0.4 \mathrm{~mm})$ wrapped around their shells and adhered with 'super glue'. Shells were dried and sanded before application. $M$. granulata was chosen as it is ubiquitous on Kenyan reefs and its shell shape allowed for good adherence to the monofilament. Within the Malindi North, Watamu, Kanamai and Diani reefs 10 experimental individuals were attached to nylon transect lines at $2 \mathrm{~m}$ intervals along the line. Three transect lines were placed within each reef flat and lagoon site, except Watamu, where only the reef lagoon was studied. Transects were visited every $24 \mathrm{~h}$ for $3 \mathrm{~d}$. Missing individuals were recorded and assumed to represent predation or attempted predation. Control individuals $(n=15)$ were placed in sea water tanks for the same time period to determine if individuals might become detached from the monofilament due to seawater immersion. Comparisons of survival between reef flats and reef lagoons, protected and unprotected reefs, and the effect of predation on gastropod density and diversity were undertaken.

\section{RESULTS}

Although observers moved at significantly different rates, comparisons between observers indicate a close agreement in the numbers of species and individuals observed (Table 1). The 2 observers used different strategies. The author moved at approximately twice

Table 1. Comparison of number of species and individuals ( $\overline{\mathrm{x}}$ $\pm \mathrm{SD})$ found during $1 \mathrm{~h}$ sampling periods $(n=17)$ by 2 independent observers working within the same location, and their rates of movement $(n=15)$. Mann Whitney $U$-test comparison between observers. NS: not significant, $\cdots$ $p<0.001$

\begin{tabular}{|lccc|}
\hline & Species $^{-1}$ & Ind. $^{-1}$ & ${\text { Paces } 30 \mathrm{~s}^{-1}}^{-1}$ \\
\hline Observer 1 & $13.06 \pm 4.96$ & $56.82 \pm 43.31$ & $21.93 \pm 4.64$ \\
Observer 2 & $13.53 \pm 6.77$ & $66.11 \pm 49.59$ & $11.73 \pm 6.42$ \\
Significance & $\mathrm{NS}$ & $\mathrm{NS}$ & $\ldots$ \\
\hline
\end{tabular}

the speed of the second observer but maintained a narrow $1 \mathrm{~m}$ field of vision compared to the second observer's $2 \mathrm{~m}$ field of vision. Consequently, the author covered $1450 \mathrm{~m}^{2} \mathrm{~h}^{-1}$ compared to $1270 \mathrm{~m}^{2} \mathrm{~h}^{-1}$ for the second observer. As some individuals were probably missed, an area of $1000 \mathrm{~m}^{2} \mathrm{~h}^{-1}$ can probably be taken as an approximate time-to-spatial conversion.

During the total sample 127 species from 25 families were recorded (species list and densities available on request from the author). Their distribution was highly variable. Comparisons between reef locations indicates low average similarity indices (Sørenson's Index) for the 10 most common species within reef edges $(0.33 \pm$ $0.11, \bar{x} \pm S D)$, reef flats $(0.41 \pm 0.13)$, reef lagoons $(0.44$ $\pm 0.15)$ and particularly for all comparisons (0.25 \pm $0.16)$. Analysis of gastropod percent family composition (Fig. 2) indicates a similarity between edges and flats, the dominance of the Thaididae, and the importance of the Conidae, Vasidae (=Turbinellidae) and Cypraeidae. A Wilcoxon rank sum test found no significant differences in family composition for locations or management categories. In terms of trophic rank, this analysis shows that most gastropods on reef flats and edges are predators. Thaididae appear to dominate the unprotected reefs whereas protected sites appear to have a greater relative abundance of cypraeids. Reef lagoons have a more even partitioning of the relative 

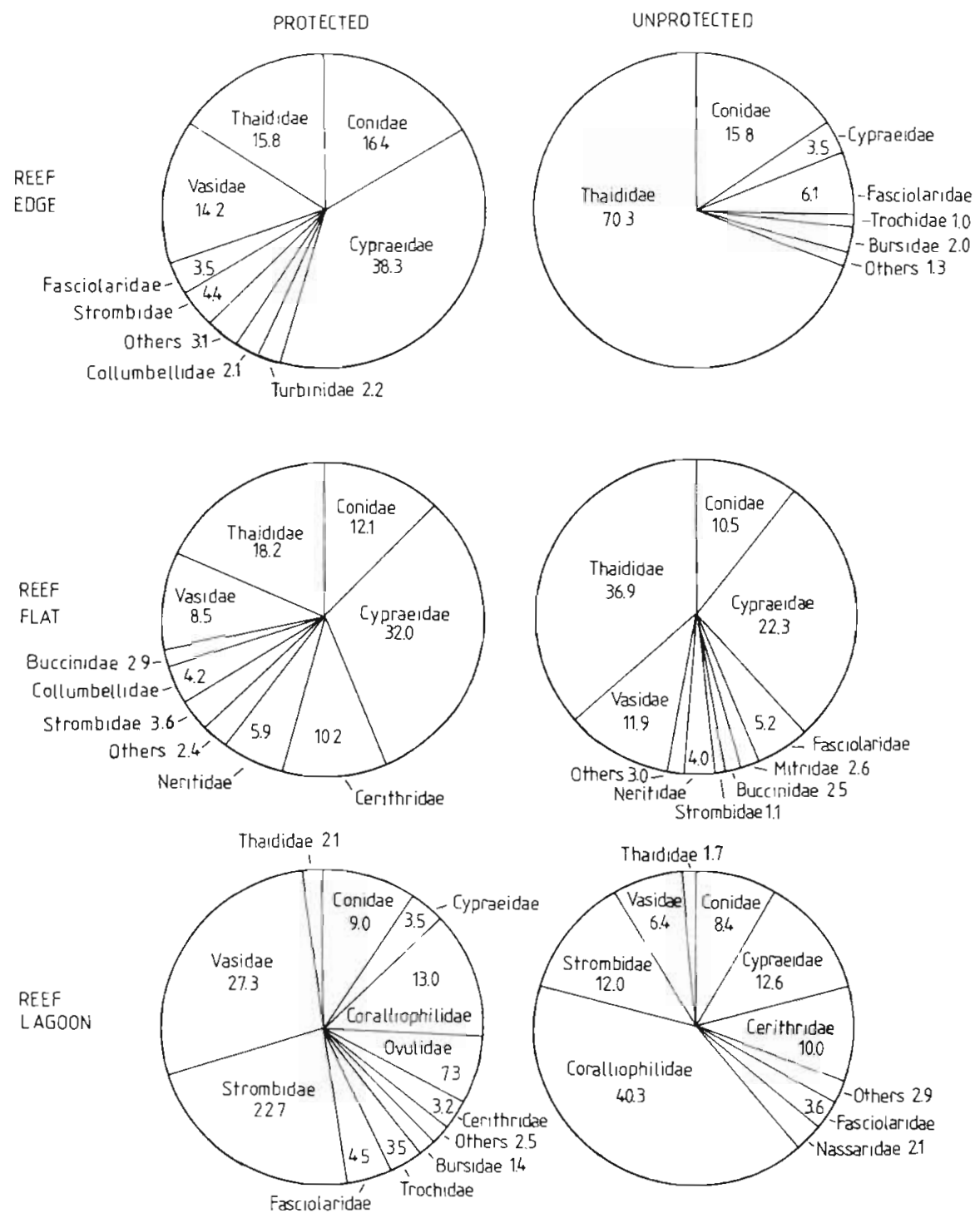

Fig. 2. Family composition of the gastropod fauna on protected and unprotected reefs encountered within the various reef locations. (Thaididae $=$ Murcidae, Vasidae $=$ Turbinellidae)

abundance of families and consequently a greater trophic diversity. Soft and hard corallivorous gastropods, Ovula ovum and Coraliophila violacea, and the detritivorous/herbivorous Strombidae, appear relatively more important within lagoons. Within unprotected reef lagoons, particularly Diani, a large population of Coraliophila violacea dominates and increases the relative importance of the Coralliophilidae. No Ovulidae and fewer Strombidae were found within unprotected reefs.

Density and diversity measurements indicate low density and high diversity for most sites (Tables 2 and 3). Densities on reef edges and flats were, in general, of magnitude 1 gastropod per $10 \mathrm{~m}^{2}$. Reef flats and edges had the highest densities and comparisons between protected and unprotected reefs are not significant (Table 2). Protected reef lagoons had lower densities on the order of 1 per $100 \mathrm{~m}^{2}$ but gastropod densities were significantly higher in unprotected reef lagoons (Table 2). Diversity, as measured by Simpson's Index, is high for most sites and there are no clear distinctions between edge, flat and lagoon sites. Comparisons between protected and unprotected sites indicate that the total diversity of protected areas $(D=$ $0.88 \pm 0.14, \overline{\mathrm{x}} \pm \mathrm{SEM}$ ) is greater, although just short of significantly so (Mann-Whitney $U$-test, $p=0.056$ ), than unprotected sites $(D=0.78 \pm 0.05)$. This may, in part, be attributed to the high relative densities of certain species such as Coraliophila violacea within Diani's reef lagoon, Drupa morum on Kanamai and Bamburi's reef edges and Cypraea annulus and Morula granulata on reef flats.

Comparisons of individual species population densities (Table 4) indicate low densities and high variability for most species. Many of the common commercial species such as Charonia tritonis, Cypraecassis 
rufa, Turbo marmarotus, Chicoreus ramosus and Cassis cornuta were found at very low densities in both protected and unprotected sites and therefore not amenable to statistical comparison. Results of a comparison between protected and unprotected reefs, combining these and 21 other commercial species, were insignificant. Comparisons of densities of the 15 more common commercial species indicates that average densities were often higher within protected reefs but only 4 species were statistically $(p<0.05)$ denser. Seven species were denser at the $p<0.10$ level. One commercial species, Conus leopardus, was denser within unprotected reefs. Comparing noncommercial species indicates that 10 comparisons were not significant, 2 species were denser and 3 less dense in unprotected than in protected reefs. Using the noncommercial species as expected frequencies in a G-test (Sokal \& Rohlf 1981) indicates that commercial species are frequently denser $(p<0.02)$ in protected than in unprotected reefs.

Species-time curves (Fig. 3) indicate that protected reef lagoons and edges have more species per area, as lagoons had significantly higher (t-test, $p<0.01) z$ values and reef edges significantly higher $(p<0.01) C$ values. Reef flats were similar by this comparison. Species as a function of individuals (Fig. 4) also had higher $(p<0.01) z$ values for reef lagoons and edges but lower $(p<0.01) z$ values for reef flats. It is clear that absolute species richness will depend on the total area of the reef and gastropod density. Although protected reef lagoons have higher $z$ values very large areas may be necessary before the absolute number of species is greater than within unprotected reefs.

Results of the predation experiment (Table 5) indicate that removal rates were low. Comparisons between reef flat and lagoons indicate that lagoons had higher predation rates, althouth the difference is short of significant (Mann Whitney $U$-test, $p=0.07$ ). Survival in protected lagoons $(2.51 \pm 1.02 \mathrm{~d}, \overline{\mathrm{x}} \pm \mathrm{SD})$ was also just short of being significantly lower $(p=0.55)$ than in unprotected reef lagoons $(2.92 \pm 0.38 \mathrm{~d})$. The experiment might have been improved by increasing its duration. Nevertheless, gastropod density at the studied sites was well predicted by the predation rate (predation rate $=$ total length of experiment $(3 d)-$ survival (d)) and fit well to a negative exponential curve (Fig. 5). Straight-line correlations of predation versus Simpson's Index and $z$ were positive $(D, r=0.52 ; z, r=0.62$ ) but short of significant at the given degrees of freedom.

\section{DISCUSSION}

The sampling method used within this study has the 2 weaknesses of (1) having no absolute measure of density and (2) the possibility of observer bias when 
Table 3. Diversity (Simpson's Index) of the prosobranch fauna at each reef site and location

\begin{tabular}{|c|c|c|c|c|c|c|}
\hline & $\begin{array}{l}\text { Malindi } \\
\text { north reef }\end{array}$ & $\begin{array}{c}\text { Protected reefs } \\
\text { Malindi } \\
\text { fringing reef }\end{array}$ & Kisite & Diani & $\begin{array}{l}\text { Kotected } \\
\text { Kanamai }\end{array}$ & Bamburi \\
\hline Reef edge & 0.90 & 0.83 & 0.87 & 0.90 & 0.66 & 0.77 \\
\hline Reef flat & 0.92 & 0.90 & 0.79 & 0.84 & 0.75 & 0.89 \\
\hline Reef lagoon & 0.91 & $0.90^{\mathrm{a}}$ & 0.88 & 0.44 & 0.85 & 0.92 \\
\hline
\end{tabular}

Table 4. Comparison of density no. $\mathrm{h}^{-1}, \mathrm{x} \pm \operatorname{SEM}(n)$ of commercial and noncommercial species found within marine parks and unprotected reefs. NS: not significant $+\mathrm{p}<0.10, \cdots<0.05, \cdots p<0.01, \cdots p<0.001$

\begin{tabular}{|c|c|c|c|c|c|c|}
\hline \multicolumn{4}{|c|}{ Commercial species } & \multicolumn{3}{|c|}{ Noncommercial species } \\
\hline & Protected & Unprotected & & & Protected & Unprotected \\
\hline Lambis chiragra & $0.94 \pm 0.36(16)$ & $0.0(16)$ & $\cdot$ & Nerita albicilla & $2.00 \pm 1.06(26)$ & $1.39 \pm 0.86(27) \mathrm{NS}$ \\
\hline Lambis lambis & $1.31 \pm 0.42(16)$ & $0.83 \pm 0.31(16)$ & NS & Cerithrium caeruleum & $8.40 \pm 5.09(10)$ & $0.0(11)$ \\
\hline Lambis truncata & $1.13 \pm 0.68(16)$ & $0.0(16)$ & $\cdot$ & Cerithrium piperitum & $0.12 \pm 0.12(26)$ & $1.84 \pm 1.02(27)+$ \\
\hline Strombus lentiginosus & $0.25 \pm 0.10(16)$ & $0.39 \pm 0.20(16)$ & NS & Strombus gibberulus & $1.06 \pm 0.41(39)$ & $1.43 \pm 0.46(36) \mathrm{NS}$ \\
\hline Cypraea annulus & $12.81 \pm 2.87\{39\}$ & $6.79 \pm 1.96(36)$ & + & Strombus mutabilis & $0.95 \pm 0.47(39)$ & $0.70 \pm 0.44(36) \mathrm{NS}$ \\
\hline Cypraea lynx & $3.13 \pm 1.08(23)$ & $1.70 \pm 0.92(20)$ & NS & Coralliophila violacea & $2.28 \pm 0.87(16)$ & $19.13 \pm 11.6(16) \mathrm{NS}$ \\
\hline Cypraea moneta & $0.77 \pm 0.28(23)$ & $0.21 \pm 0.17(20)$ & + & Morula graunlata & $2.21 \pm 1.33(23)$ & $13.48 \pm 2.66(20) \cdots$ \\
\hline Cypraea tigris & $1.38 \pm 0.47(39)$ & $0.61 \pm 0.18(36)$ & NS & Morula squamosa & $2.00 \pm 0.94(23)$ & $5.05 \pm 1.50(20) \mathrm{NS}$ \\
\hline Ovula ovum & $1.31 \pm 0.76(16)$ & $0.0(16)$ & + & Thais distinguenda & $2.43 \pm 0.96(23)$ & $0.10 \pm 0.10(20) \mathrm{NS}$ \\
\hline Pleuraploca trapezium & $0.81 \pm 0.26(16)$ & $1.23 \pm 0.27(16)$ & NS & Thais tuberosa & $4.87 \pm 1.39(23)$ & $4.87 \pm 1.07(20) \mathrm{NS}$ \\
\hline Vasum ceramicum & $1.52 \pm 0.41(36)$ & $0.08 \pm 0.06(36)$ & $\cdots$ & Engina mendicaria & $1.26 \pm 0.47(23)$ & $1.25 \pm 0.57(20) \mathrm{NS}$ \\
\hline Conus chaldeus & $0.60 \pm 0.16(23)$ & $0.10 \pm 0.07(20)$ & $\cdot$ & Vasum rhinocerus & $1.07 \pm 0.28(39)$ & $3.77 \pm 0.53(36)+$ \\
\hline Conus ebraeus & $1.60 \pm 0.50(23)$ & $1.11 \pm 0.49(20)$ & NS & Vasum turbinellus & $4.49 \pm 1.05(39)$ & $0.76 \pm 0.23(36) \cdots$ \\
\hline Conus leopardus & $0.26 \pm 0.13(16)$ & $1.34 \pm 0.36(16)$ & $\cdot$ & Conus ceylensis & $0.53 \pm 0.13(39)$ & $0.24 \pm 0.12(36) \mathrm{NS}$ \\
\hline Conus miles & $0.38 \pm 0.15(39)$ & $0.25 \pm 0.08(36)$ & NS & Conus lividus & $1.28 \pm 0.37(39)$ & $1.44 \pm 0.41(36) \mathrm{NS}$ \\
\hline Others (26 species) & $1.31 \pm 0.32(39)$ & $1.05 \pm 0.23(36)$ & NS & & & \\
\hline
\end{tabular}

comparing results. Results suggest that observer bias is small but this may be because both observers were experienced in coral reef survey methods. I suggest that future researchers using this method familiarize themselves with the method and fauna before collecting data, that they quantify their rates of movement and fields of vision, and compare themselves with another observer when possible. Despite the drawbacks, the method has the distinct advantage of time efficiency in the intertidal zone. This allows observers to cover large areas within reefs and to complete large surveys within reasonable time limits. Additionally, many ecological measures such as diversity and species richness can be calculated from the results.

Results suggest that Kenya's coral reef-associated gastropod fauna, like other tropical Indo-Pacific regions, is typified by low density and high variability and diversity (Kohn 1959, 1968, Kohn \& Nybakken 1975, Reichelts 1982). These 3 factors make generalizations difficult but some patterns emerge. Species composition between similar sites show high variability but there were frequently unquantified differences in reef height, water depth, substrate type and wave energy that may have accounted for this variation. These differences may have overridden divisions based on reef location, particularly when comparing reef edge and flat sites. Prior reasoning for dividing these 2 locations was that reef edge sites appeared to experience greater wave energy than flats. Yet, this difference was not always consistent due to variations in aspect and the reef's protection from waves. Nonetheless, some species were consistently found on reef edges with high energy and seldom on reef flats, just as others were generally restricted to reef flats. Additionally, some species were ubiquitous and not strongly associated with any site. I suggest that this gastropod fauna is not a group of highly interacting species creating a community, but is affected by external biological and physical factors such as substrate, water movements, desiccation stress, recruitment and predation by other taxonomic groups (i.e. finfish, crabs) that affect their distribution and limit their population densities. These external factors may, coincidentally, affect other species distributions creating a community of diverse taxonomic assemblages. 
Fig. 3. Species-time curves (no. of species found per time spent sampling) and equations of the form $y=C x^{z}$ comparing species richness between protected $(\bullet)$ and unprotected reefs $(0)$. Bars: $\pm 1 \mathrm{SD}$; sample sizes given in brackets
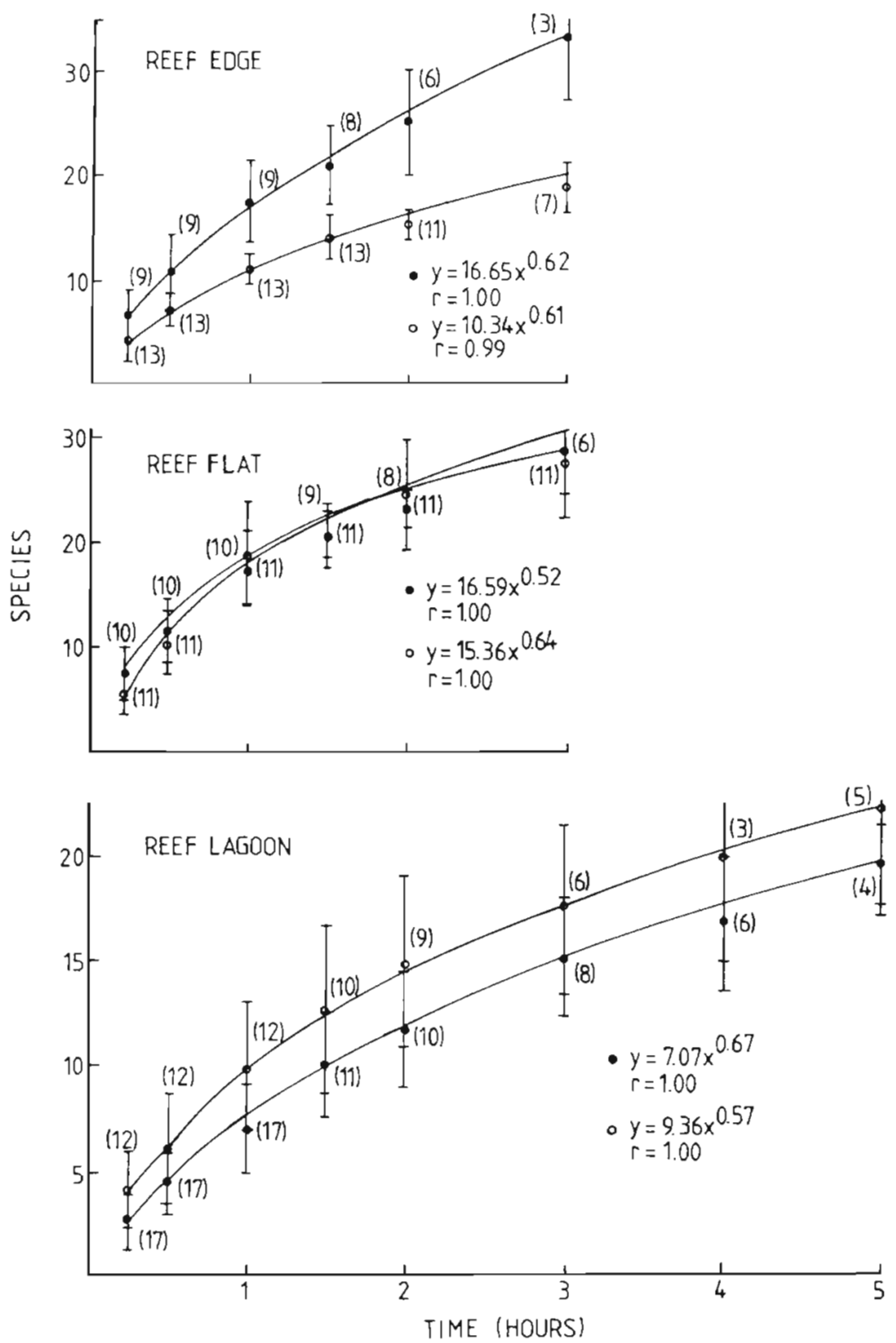

Prior to reports by Leviten \& Kohn (1980) and Reichelt (1982), a great deal of research on cone shells focused on possible resource partitioning mechanisms (Kohn 1959, 1968, 1971, Kohn \& Nybakken 1975, Leviten 1978). The latter research suggested that cone shells have diverse diet, depth and substrate requirements that could allow for species coexistence. However, Reichelt (1982) concluded that space is not a limiting resource and Leviten \& Kohn (1980) concluded that nonequilibrium factors such as intense storms may keep these species at densities below levels that require interspecific coexistence mechanisms. East African coral reefs rarely experience large storms and waves apart from seasonal monsoons of low intensity (McClanahan 1988). Additionally, reef lagoons, which have the lowest gastropod densities, would not be subjected to their influence. Yet, Conus densities reported here are as low or lower than other regions (Kohn 1959, 1968, Kohn \& Nybakken 1975). The predation data presented here suggests that predation on adults is low, but may influence gastropod densities and distribution patterns. Our study supports the hypothesis that gastropods, like other coral reef populations, are regulated by density-independent factors (Shulman \& Ogden 1987) but not that they are nonequilibrium assemblages; they may be in equilibrium with their predators. Early post-settlement mortality (Perron 1983, Victor 1986, Shuiman \& Ogden 1987) may result in low adult population densities. Topographic complexity, which has been shown to increase population densities and diversity (Kohn \& Leviten 1976), creates refuge from predators which allows for population persistence. 


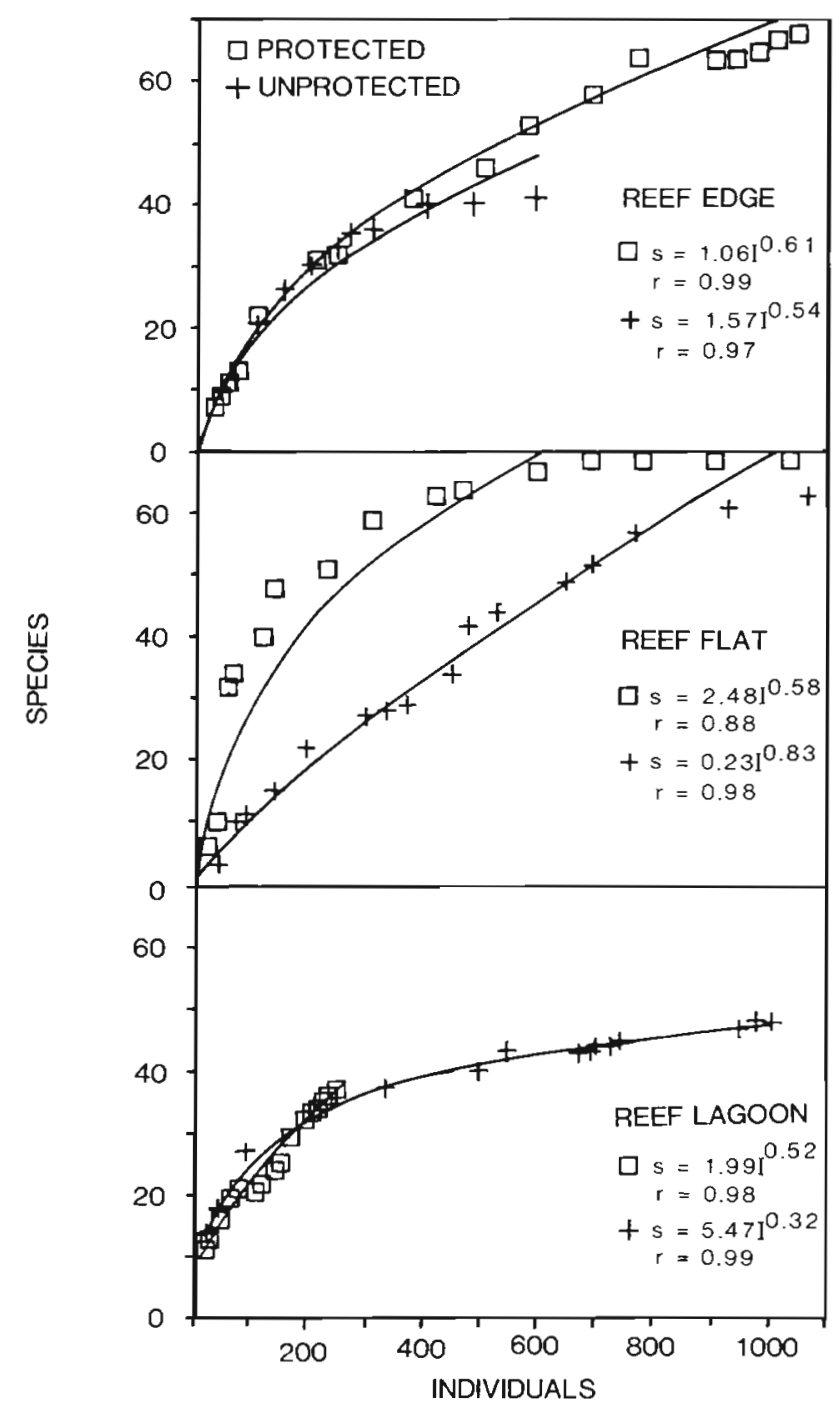

Fig. 4. Species-individual curves for the various reef locations

Considering that most gastropod species have low densities, high variability and low respiration rates suggests that they are not important in determining coral reef community structure or influencing energetics. Laboratory and field experiments on one gastropod, the sea urchin predator Cypraecassis rufa, (McClanahan \& Muthiga 1989) indicated low predation rates on sea urchins compared to predation by finfish. Consequently, their removal through shell collecting is

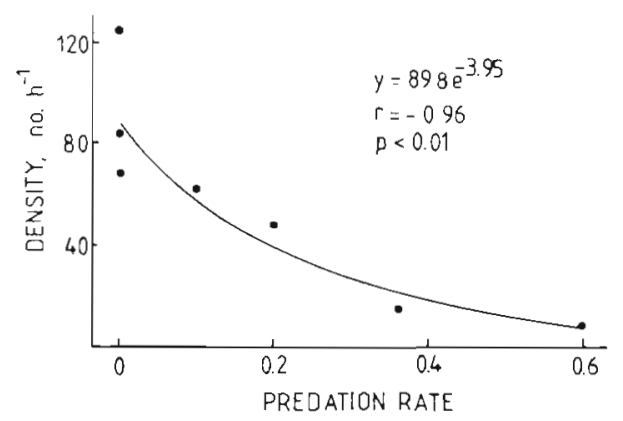

Fig. 5. Total gastropod density as a function of predation rates on Morula granulata within the 7 studied locations

likely to have less effect on reducing sea urchins with their destructive effects on coral reefs (McClanahan \& Muthiga 1988) than is finfish removal. Environmental concerns about shell collecting may be overstated and might be better focused on overfishing of finfish.

Comparing protected and unprotected reefs suggests some differences, but teasing apart factors affecting these differences, such as inherent site differences, shell collecting and fishing, remains difficult. In general, protected reefs have a higher diversity and a higher density of some collected species. Differences are however not great and some differences may be caused by factors other than shell collecting. Unprotected reef edges had fewer species per area than protected reefs and a greater dominance of the Thaididae. It is likely that this difference is due to greater wave energy on unprotected reef edges, although shell collecting may have contributed to the lower densities of cypraeids within these areas. Within reef lagoons, site differences are less likely to be important and lower densities of Lambis truncata, L. chiragra and Ovula ovum can be attributed to shell collecting in unprotected areas. Yet, it is also notable that densities of many collected species are not lower in unprotected areas.

Higher gastropod densities within unprotected versus protected lagoons is a consistent but less intuitively clear pattern. McClanahan \& Muthiga (1988, 1989) show that sea urchin densities are higher and fish densities lower on unprotected reefs. Ayling (1981) found a positive correlation between sea urchin and gastropod densities and suggested that sea urchins

Table 5. Morula granulata. Survival rate in days $(\overline{\mathrm{x}} \pm \mathrm{SD}(\mathrm{n}))$ for a $3 \mathrm{~d}$ period within reef flats and lagoons at 4 sites. Control survival $=3.0 \pm 0.0$ (15)

\begin{tabular}{|lccccc|}
\hline & \multicolumn{2}{c}{ Protected } & \multicolumn{2}{c|}{ Unprotected } \\
& Malindi & Watamu & Kanamai & Diani & Totals \\
\hline Reef flats & $2.90 \pm 0.55(30)$ & - & $3.0 \pm 0.0(30)$ & $3.0 \pm 0.0(30)$ & $2.97 \pm 0.32(90)$ \\
Reef lagoons & $2.64 \pm 0.99(25)$ & $2.40 \pm 1.04(30)$ & $2.8 \pm 0.61(30)$ & $3.0 \pm 0.0(30)$ & $2.72 \pm 0.78(115)$ \\
\hline
\end{tabular}


modify the substrate enhancing conditions for grazing gastropods. Results of our gastropod and sea urchin predation studies (McClanahan \& Muthiga 1989) indicate that both taxonomic groups have responded to reductions in finfish predators. I suggest that predation is a dominant controlling force for many invertebrate species within coral reef lagoons and that finfish removal through fishing activities can greatly affect invertebrate community composition.

The low densities of many important commercial shell species, regardless of management strategy, is a notable result of this survey. Factors likely to explain this include (1) sampling at times or places not coincident with their distribution and diurnal activity patterns, (2) poaching within protected reefs, (3) naturally low densities and (4) populations within protected reefs not having recovered since the Park's inception. The first factor (sampling) might well explain some differences as many species are nocturnally active and cryptic during daylight. This is particularly true of Cypraecassis rufa which hides in coral sand during daylight. Nocturnal sampling would likely result in greater densities (Yaninek 1978). Species such as Charonia tritonis may naturally occur at low densities (Ormand \& Campbell 1971). Large species may also have slow growth rates (Honma 1988) and recovery after collection may require a long time. Poaching is probably erratic and a less important factor. It is likely that the densities of these species are naturally low but all of the above factors may have influenced this result.

Acknowledgements. I am grateful for the assistance of $\mathrm{N}$. A. Muthiga, J. Mariara, M. Carey, M. Feuerstein and the Malindi-Watamu and Kisite Marine National Park Staff for field assistance, the Office of the President for research clearance and the Kenya Marine and Fisheries Research Institute and Center for Wetlands for logistical support. This study received financial support from IUCN and the East African Wildife Society.

\section{LITERATURE CITED}

Abbott, R. T., Dance, S. P. (1986). Compendium of seashells. American Malacologists, Melbourne, Florida

Ayling, A. M. (1981). The role of biological disturbance in temperate subtidal encrusting communities. Ecology 62 : $830-847$

Brownell, W. N., Stevely, J. M. (1981). The biology, fisheries and management of the queen conch, Strombus gigas. Mar. Fish. Rev. 43: 1-12

Catterall, C. P., Poiner, I. R. (1987). The potential impact of human gathering on shellfish populations, with reference to some NE Australian intertidal flats. Oikos 50: 114-122

Evans, S. M., Knowles, G., Pye-Smith, C., Scott, R. (1977). Conserving shells in Kenya. Oryx 13: 480-485

Hay, M. E. (1984). Patterns of fish and urchin grazing on Caribbean coral reefs: are previous results typical? Ecology 65: $446-454$
Hay, M. E., Taylor, P. R. (1985). Competition between herbivorous fishes and urchins on Caribbean reefs. Oecologia (Berl.) 65: 591-598

Honma, K. (1988). Growth of coral-reef gastropods Trochus niloticus and Turbo marmoratus. Galaxea 6

Hughes, T P., Reed, D. C., Boyle, M. (1987). Herbivory on coral reefs: community structure following mass mortalities of sea urchins. J. exp. mar. Biol. Ecol. 113: 39-59

Knowles, G. (1970). Shell-collecting in Kenya. Report of the University of Newcastle-upon-Tyne Exploration Society's Expedition to Kenya

Kohn, A. J. (1959). The ecology of Conus in Hawaii. Ecol. Monogr. 29: 47-90

Kohn, A. J. (1968). Microhabitats, abundance and food of Conus on atoll reefs in the Maldive and Chagos Islands. Ecology 49: 1046-1062

Kohn, A. J. (1971). Diversity, utilization of resources, and adaptive radiation in shallow-water marine invertebrates of tropical oceanic islands. Limnol. Oceanogr. 16: 332-348

Kohn, A. J., Nybakken, J. (1975). Ecology of Conus on Eastern Indian Ocean fringing reets: diversity of species and resource utilization. Mar. Biol. 29: 211-239

Kohn, A. J., Leviten, P. J. (1976). Effect of habitat complexity on population density and species richness in tropical intertidal predatory gastropod assemblages. Oecologia (Berl.) 25: 119-210

Leviten, P. J. (1978). Resource partitioning by predatory gastropods of the genus Conus on subtidal Indo-Pacific coral reefs: significance of prey size. Ecology 59: 614-631

Leviten, P. J., Kohn, A. J. (1980). Microhabitat resource use, activity patterns, and episodic catastrophe: Conus on tropical intertidal reef rock benches. Ecol Monogr. 50: 55-75

Lewis, S. M. (1986). The role of herbivorous fishes in the organization of a Caribbean reef community. Ecol. Monogr. 56: 183-200

McClanahan, T R. (1988). Seasonality in East Africa's coastal waters. Mar. Ecol. Prog. Ser. 44: 191-199

McClanahan, T. R., Muthiga, N. A. (1988). Changes in Kenyan coral reef community structure due to exploitation. Hydrobiologia 166: 269-276

McClanahan, T. R., Muthiga, N. A. (1989). Patterns of predation on a sea urchin, Echinometra mathaei (de Blainville), on Kenyan coral reefs. J. exp. mar. Biol. Ecol. (in press)

Ormand, R. F. G., Campbell, A. C. (1971). Observations on Acanthaster planci and other coral reef echinoderns in the Sudanese Red Sea. In: Stoddart, D. R., Yonge, M. (eds.) Regional variation in the Indian Ocean coral reefs, Symp. Zool. Soc. Lond. 28. Academic Press, London, p. 501-534

Perron, F. E. (1983). Growth, fecundity and mortality of Conus pennaceus in Hawaii. Ecology 64: 53-62

Poiner, R., Catterall, C. P. (1988). The effects of traditional gathering on populations of the marine gastropod Strombus luhuanus Linne 1758, in southern Papua New Guinea. Oecologia (Berl.) 76: 191-199

Reichelt, R. E. (1982). Space: a non-limiting resource in the niches of some abundant coral reef gastropods. Coral Reefs 1: 3-11

Routledge, J. D. (1979). Diversity indices: which ones are admissible? J. theor, Biol. 76: 503-515

Sammarco, P. W. (1980). Diadema and its relationship to coral spat mortality: grazing, competition and biological disturbance. J. exp. mar Biol. Ecol. 45: 245-272

Sammarco, P. W. (1982). Echinoid grazing as a structuring force in coral communities: whole reef manipulations. J. exp. mar. Biol. Ecol. 61: 31-55

Shulman, M. J., Ogden, J. C. (1987). What controls tropical reef fish populations: recruitment or benthic mortality? An 
example in the Caribbean reef fish Haemulon flavolineatum. Mar. Ecol. Prog. Ser. 39: 233-242

Sokal, R. R., Rohlf, F. J. (1981). Biometry, 2nd edn. W. H. Freeman and Co., San Francisco

Spry, J. F. (1968). The sea shells of Dar es Salaam: 1 Gastropods. Tanzania Society, Dar es Salaam

Victor, B. C. (1986). Larval settlement and juvenile mortality in a recruitment-limited coral reef fish population. Ecol. Monogr. 56: 145-160

Yaninek, J. S. (1976). Survey of gastropod populations at Diani

This article was submitted to the editor and at Malindi Marine National Park, Kenya. J. East Afr. nat. Hist. Soc. Nat. Mus. 31 (159): 1-10

Yaninek, J S. (1978). A comparative survey of reef-associated gastropods at Maziwi Island, Tanzania. J. East Afr. nat. Hist. Soc. Nat. Mus. 31 (165): 1-16

Wells, S. M. (1981). International trade in ornamental corals and shells. Proc. 4th Int. Coral Reef Symp., Manila I: 323-330

Wells, S. M., Pyle, R. M., Collins, N. M. (1983). The IUCN red data book. IUCN, Gland, Switzerland

Manuscript first received: July 1, 1988

Revised version accepted: January 27, 1989 